\title{
A new cave amphipod Crustacea from Japan ${ }^{1)}$
}

\author{
By Masuzo UÉNO2)
}

with plates 81 (1)-82 (2) and 1 figure in the text.

Awacaris n. gen.

Eyes absent. First antenna longer than second antenna, accessory flagellum 1-jointed. Mandibular palp normal, joint 3 longer than 2, armed with several spines on distal half. First maxilla, palp very small, shorter than outer plate, with 1 apical seta; inner plate short and broad, bearing 10-12 plumose setae. Coxal plates comparatively small. Gnathopods 1 and 2 short and slender, subchelate. Hind lower corners of metasome segments not produced behind. Pleopods normal. Third uropod with two rami almost of the same length, outer ramus 1 -jointed. Telson longer than broad, cleft deep but not reaching to base, with each lobe converging toward apex and bearing 1 apical spinule.

Type-species: Awacaris kawasawai n. sp.

\section{AWACARIS KAWASAWAI n. sp.}

Material: Holotype, female, paratypes 8 females, with 6 juv. from Himisé-dô Cave in Shikoku. None of the specimens have a marsupium, but all of them are probably females. The specimens of the type-series are deposited in the collection of the Department of Zoology, National Science Museum, Tokyo.

\section{Description:}

Length of body $5.0 \mathrm{~mm}$ (from front of head to the end of third uropod). Body and appendages depigmented and somewhat translucent. Eyes absent. Head large, nearly as long as the first two body segments combined, front lower corner protruding and obtuse, no rostrum. Dorsal surface of body smooth. First antenna about as long as the first seven body segments,

1) Contribution No. 67 from the Spelaeological Society of Japan.

2) Sakurazuka-Hondori $2-18$, Toyonaka-shi near Osaka, Japan. 
peduncle short, flagellum consisting of 20 joints; accessory flagellum 1 -jointed, conical, about $1 / 4$ the length of first joint of primary flagellum, bearing 3 apical setae. Second antenna about $3 / 5$ the length of first antenna, flagellum composed of 12 joints. Gland cone prominent.

Upper lip rounded and symmetrical. Mandible, cutting edge armed with a row of incisions, accessory plate almost as long as cutting edge, two-forked in the right, not forked and with a row of incisions in the left, spine-row of 3 pairs in the right, of 5 pairs in the left; molar prominent, triturating surface carrying a long plumose seta; palp 3-jointed, third joint longest, with 8 spines on distal half of inner margin. Maxilla 1, inner plate short and broad, with 9-10 spine-like pectinate teeth on apical margin; palp very small, shorter than outer plate, 2-jointed, second joint shorter than the first, tapering toward apex, with a single long apical seta. Right and left palps differ from each other only in the length of second joint. Maxilla 2, inner and outer plates about the same length, inner plate with a diagonal row of spines. Maxilliped, inner plate a little shorter than outer plate and reaching to nearly the distal end of second joint of palp, armed apically with 2 large flat teeth and a number of plumose setae which extend down the inner margin; outer plate armed distally with rows of long spines; palp 4-jointed, second and third joints subequal in length. Lower lip without inner lobes, outer lobes broad, with short lateral processes.

Coxal plates comparatively small, $1-4$ not deeper than their respective body segments, the first two with rounded lower margin, third slightly narrowed distally, fourth broader than the preceding three and with evenly rounded lower and concave rear margins. Coxal plate 5, lower margin incised, 6 with a shallow frontal part, and 7 semicircular.

Gnathopod 1 shorter than gnathopod 2, second joint a little expanded and a little shorter than fifth and sixth combined; fifth joint longer than sixth, with 3 spines on rear margin; sixth joint narrowing distally, front margin with about 4 spines, rear margin with 3 groups of long spines, outer surface with a diagonal row of 5 short spines; palm slightly convex, seventh joint longer than palm. Gnathopod 2, fifth and sixth joints longer and slenderer than those of gnathopod 1, rear margin of fifth joint armed with 6 groups of long spines, sixth joint a little shorter than fifth, slightly narrowing distally, with 4 groups of long spines, palm convex, with 3-4 spines at hind end, seventh joint longer than palm.

Pereiopods 1 and 2 slender and about the same form, but 2 a little shorter than 1; second joint a little expanded, as long as fourth and fifth joints combined, the latter two very little expanded, seventh joint a little shorter than half the length of sixth joint, with $1-2$ spinules on inner margin near tip. Pereiopods 3, 4 and 5 longer than 1 and 2, and 3 shorter than 4 and 5, the latter two subequal in length; second joint shorter in pereiopod 3 than 
in 4 and 5, the latter two subequal, expanded, front and rear margins nearly straight in 3 , slightly convex in 4 and 5 , converging especially in 4 , both margins slightly serrate and spinose; seventh joint half the length of sixth joint, with 2 spinules on inner margin near tip. Branchiae present on gnathopod 2 and pereiopods $1-4$, that of gnathopod 2 small and finger-like form, those of pereiopods 1 and 2 elonagte oval, and those of pereiopods 3 and 4 long and slender.

Epimeral plates of metasome segments with lower margin evenly rounded in 1 and 2, straight in 3, with rear margin straight in 2 and convex in 3, hind angles of 2 and 3 obtuse; all the plates without spinulation on margins. Pleopods well developed, both rami subequal in length, outer ramus 8 -jointed, inner ramus $6-7$-jointed in all of three pairs, each joint with a long seta on each side, apical joint with 2 setae. A small process directed backwards present near base on inner side of outer ramus of pleopods 1 and 2 .

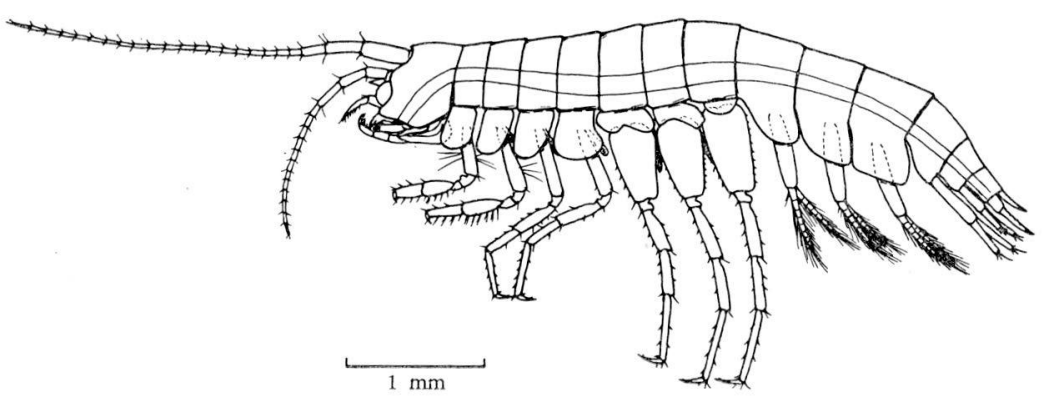

Awacaris kawasawai n. gen. et n. sp.: female from Himisé-do Cave in Tokushima Prefecture, Shikoku.

Uropod 1 extends beyond uropod 2, uropod 3 extending a little farther than uropod 1. Uropod 1, peduncle about twice as long as outer ramus, which is a little shorter than the inner, both rami armed with 3-4 apical spines. Uropod 2, peduncle reaches back to about the distal end of peduncle of uropod 1 , with only 1 spine on upper margin, outer ramus about $2 / 3$ as long as inner ramus. Uropod 3, peduncle a little over than the third part of outer ramus, with both rami nearly of the equal length (inner slightly shorter), lanceolate, each with bidentate apex, bearing 2 spinules; outer margin armed with 4 spines and 4 plumose setae and inner margin with 2 spines and 2 plumose setae. Telson reaches back to about the middle of 
uropod 3, twice as long as broad, cleft reaching to $3 / 4$ from apex, its bottom concave; each lobe slender, converging toward bidentate apex, at which bears a single spinule, and with 1 seta on lateral margin.

Male unknown.

Locality: Himisé-dô, a limestone cave that lies at Nagayasu near the town of Kaminaka-chô, Tokushima Prefecture (Province of Awa) in Shikoku. The specimens were collected by $\mathrm{T}$. Kawasawa and $\mathrm{S}$. Uéno in a subterranean stream, while exploring that cave on April 2, 1967.

Remarks and Taxonomic Notes:

The present form is characterized by the structure of its third uropod, of which both rami are almost of the same length and the outer ramus is of a single joint, as well as by the narrow telson with deep cleft. The accessory flagellum of its first antenna is rudimentary, consisting only of a single joint. Both pairs of gnathopods are short and weakly constructed. Using these characteristics, with regard to some other features particularly the first maxilla, the present specimens cannot be identified with any of the known genera of the gammarids inhabiting subterranean waters.

The present form resembles, at first sight, some species of the marine genus Maera of the Gammeridae. In this genus the third uropod has well developed two subequal rami, the outer one of which is unijointed, and the telson is deeply cleft, the apex of each lobe being bidentate or tridentate. In Maera othonis and M. loveni the apex is shallowly bidentate (Sars 1895, pl. 182) as in the present form, and in M. inaequipes such an apical notch of each lobe is large and deep (Barnard 1954). M. serratipalma from the coast of Japan (Nagata 1965) has distinctly tridentate apex. The members of Maera differ, however, from the present form in the characteristics other than the third uropod and the telson. The accessory flagella of their first antennae are of full development, consisting usually of 6-7 joints, and both pairs of gnathopods, particularly the second, are powerfully constructed. The coxal plates have often serrate margins, and the hind lower corners of the metasome segments are produced behind and often serrate. Among the known species, Maera loveni (Bruzelius) from Europe has almost obsolete eyes.

Ruffo (1956) arranged the subterranean amphipods of Europe and the neighbouring region south of the Mediterranean Sea into nine groups including Ingolfiella (the order Ingolfiellidea). On the basis of this grouping, Vandel (1965) revised the hypogeous gammarids known from the world by dividing them into nine groups (not the nine groups according to Ruffo), two of which, the Niphargus (including Ruffo's Eriopisa group) and Crangonyx groups, predominate in the number of species. The present species seems to belong to any one of the genera of the latter group in general appearance, but it differs from in some details, particularly in the gnathopods, 
the third uropods and the telson. The inner ramus of the third uropod is greatly reduced in the Crangonyx group, some of which have lost the inner ramus entirely, as in the Japanese and Korean representatives, Pseudocrangonyx and Eocrangonyx (Schellenberg 1936, Uéno 1930, 1966). In the Niphargus group too, the inner ramus is very small, while the outer ramus is well developed and has two joints, the distal one of which is often considerably long (Niphargus and Eriopisa). In this connection, the present form resembles the Hadzia group (the family Hadziidae) rather than the two groups stated above.

In the Hadzia group the inner ramus of the third uropod develops well to a size as long as the outer ramus, excepting Metaniphargus, in which the inner ramus is about one-third the length of the outer ramus. Four of the five genera which have been placed by Vandel in this group, i. e., Hadzia, Metaniphargus, Weckelia and Paraweckelia, have a minute second joint of the outer ramus ("third uropods missing" in the type-specimen of Weckelia, Schoemaker 1942), and the remaining one, the marine genus Quadrivisio, has only a single joint. The telson is cleft completely into two lobes, with the exception of Paraweckelia, in which the cleft hardly reaches to the base with the lobes widely dehiscent. As far as the third uropod is concerned, the present form agrees with the genera mentioned above, and in particular with Quadrivisio, but the telson of the latter is constructed quite otherwise. With regard to some other features, too, the present form does not correspond with the Hadzia group. The accessory flagellum of the first antenna is rudimentary in the present form, while it consists of joints from 2 to 4 and often 6 in the members of the Hadzia group. The first maxilla of the former is distinctive in having a very small palp which is not lobe-like as in most species and consists of two joints bearing only a single apical seta. The feature is comparable to the very small mandibular palp of Weckelia caeca (Weckel) which consists of only a single joint bearing two apical setae (Shoemaker 1942). The inner plate of the maxilliped of the present form is a little shorter than the outer plate and is armed with two large flat teeth on the apical margin, as in the brackish water species Metaniphargus curasavicus Stephensen (1933) from Curaçao, differing from most of the species which have three such teeth.

Although the present species has some important characteristics of both the Crangonyx and Hadzia groups, it seems to represent a new genus belonging to a distinct group rather than to either of the two. Discussing the marine origin of the hypogeous amphipods, Schellenberg (1931, 1933) indicates that Niphargus has been derived from Eriopisa, a marine genus closely resembling the former. Taking this into account he placed two Asian hypogeous species, Niphargus philippensis Chilton and N. chilkensis Chilton, in the genus Eriopisa. In this genus an anophthalmic marine species Eriopisa 
elongata (Bruzelius) has been known. As the marine origin of Niphargus has been recognized, Vandel (1965) suggests that the genus Hadzia has likewise been derived from Quadrivisio. The present species may similarly be of the marine origin. Any one species of Maera is suggested as its probable original form, from which the present species might have been derived.

Octobre 1967

\section{SUMMARY}

A new eyeless Amphipod Crustacea $5 \mathrm{~mm}$ long was found in Himisé-dō Cave in Tokushima Prefecture, Shikoku. The inner ramus of its third uropod is nearly as long as the unijointed outer ramus. The accessory flagellum of the first antenna consists only of a single joint. The first maxilla is distinctive in its small palp which does not extend beyond the apical margin of the outer plate and bears only an apical seta. In these characteristic features the present form is different from any known species of the genera of the Crangonyx and Hadzia groups and seems to belong to a new species, on the basis of which the new genus Awacaris is created.

\section{ZUSAMMENFASSUNG}

Ein neuer augenloser, $5 \mathrm{~mm}$ langer Amphipode wurde in der Himisé-dō Höhle in der Präfektur Tokushima, Shikoku, gefunden. Der Innenast seiner dritten Uropode entwickelt sich beinahe so lang wie der eingliedrige Außenast. Die Nebengeißel der ersten Antenne besteht nur aus einem einzigen Glied. Die erste Maxille ist bemerkenswert durch ihren kleinen Palpus, der sich nicht über ihre Außenlade erstreckt und eine einfache Apikalborste trägt. Durch diese charakteristischen Merkmale unterscheidet sich diese Höhlenamphipode von allen bekannten Arten der Crangonyx- oder Hadzia-Gruppe und gehört zu einer neuen Form, auf deren Grund eine neue Gattung Awacaris aufzurichten ist.

\section{REFERENCES}

Barnard, J. L. (1954) - Marine Amphipoda of Oregon. Oregon State Monogr., Studies in Zool., No. 8: 1-37, pls. 1-33.

Karaman, Stanko (1932) - Beitrag zur Kenntnis der Süßwasser-Amphipoden. Priprodoslovne Razprave, 2: 179-232.

NaGATA, K. (1965) - Studies on marine gammaridean Amphipoda of the Seto Inland Sea. III. Publ. Seto Marine Biol. Labor., 13: 291 - 326.

RufFo, S. (1956) - Lo stato attuale delle conoscenze sulla distribuzione geografica degli Anfipodi delle aeque sotteranee europee e dei paesi mediterranei. Prem. Congr. Int. de Spéléologie, Paris 1953, 3:13-37.

SARS, G. O. (1895) - An Account of the Crustacea of Norway. Vol. 1. Amphipoda. $1-711$, pls. $1-252$. ALB Cammermeyers Forlag, Christiania \& Copenhagen.

Schellenderg, A. (1931) - Amphipoden der Sunda-Expeditionen Thienemann und Rensch. Arch. Hydrobiol. Suppl.-Bd. 8, Tropische Binnengewässer, 1: $493-511$.

- (1933) - Niphargus-Probleme. Mitt. Zool. Mus. Berlin, 19: 406-429.

- (1934) - Eine neue Amphipoden-Gattung aus einer belgischen Höhle, nebst Bemerkungen über die Gattung Crangonyx. Zool. Anz., 106: 215-218.

- (1936) - Die Amphipodengattungen um Crangonyx, ihre Verbreitung und ihre Arten. Mitt. Zool. Mus. Berlin, 22: 31-44.

Shoemaker, C. R. (1942) - Notes on some American fresh-water amphipod crustaceans and descriptions of a new genus and two new species. Smithsonian Misc. Coll., 101: 1-31.

- (1959) - Three new cave amphipods from the West Indies. J. Washington Acad. Sci., 49: 273-283. 
StePHENSEN, K. (1933) - Fresh- and brackish-water Amphipoda from Bonaire, Curaçao and Aruba. Zool. Jahrb. Abt. f. System., usw., 64: 415-436.

UÉNo, M. (1930) - A new subterranean amphipod from Japan. Annot. Zool. Japon., $13: 21-23$.

- (1966) - Results of the Speleological Survey in South Korea 1966. II. Gammarid Amphipoda found in subterranean waters of South Korea. Bull. Nation. Sci. Mus., Tokyo, 9: 501-535.

VAndel, A. (1965) - Biospeleology. The Biology of Cavernicolous Animals (Engl. ed.). 1 -524. Pergamon Press, Oxford.

EXPLANATION OF PLATES 81 (1) -82 (2)

\section{1}

Awacaris kawasawai n. gen. et. n. sp.: A - accessory flagellum of antenna 1; B - upper lip; C - mandibles; D - third joint of mandibular palp; E - maxilla 1; F - maxillary palp; $\mathrm{G}$ - teeth on apical margin of outer plate of maxilla 1; $\mathrm{H}$-maxilla 2; $\mathrm{I}$ - maxilliped; $\mathrm{J}$-the same, apical margin of inner plate; $\mathrm{K}$-lower lip ; $\mathrm{L}$ - gnathopod 1 with coxal plate 1 ; $\mathrm{M}$ - the same, seventh joint; $\mathrm{N}$ - gnathopod 2 with coxal plate $2 ; \mathrm{O}$ - pleopod $1 ; \mathrm{P}$ - basal process on outer ramus of the same.

\section{2}

Awacaris kawasawai $\mathrm{n}$. gen. et n. sp.: A - pereiopod 1 with coxal plate 3 ; B pereiopod 2 with coxal plate 4 ; C - pereiopod 3 with coxal plate 5 ; D \& E - second joints of pereiopods 5 and 6 with coxal plates; F, G, H - epimeral plates of metasome segments $1-3 ; \mathrm{I}-$ uropod $1 ; \mathrm{J}-\operatorname{uropod} 2 ; \mathrm{K}$ - uropod $3 ; \mathrm{L}$ - the same, distal part of outer ramus - arrow indicates the inner side; $\mathrm{M}$ - telson and the apical part of its right lobe; $\mathrm{N}-$ teslon of another specimen. 


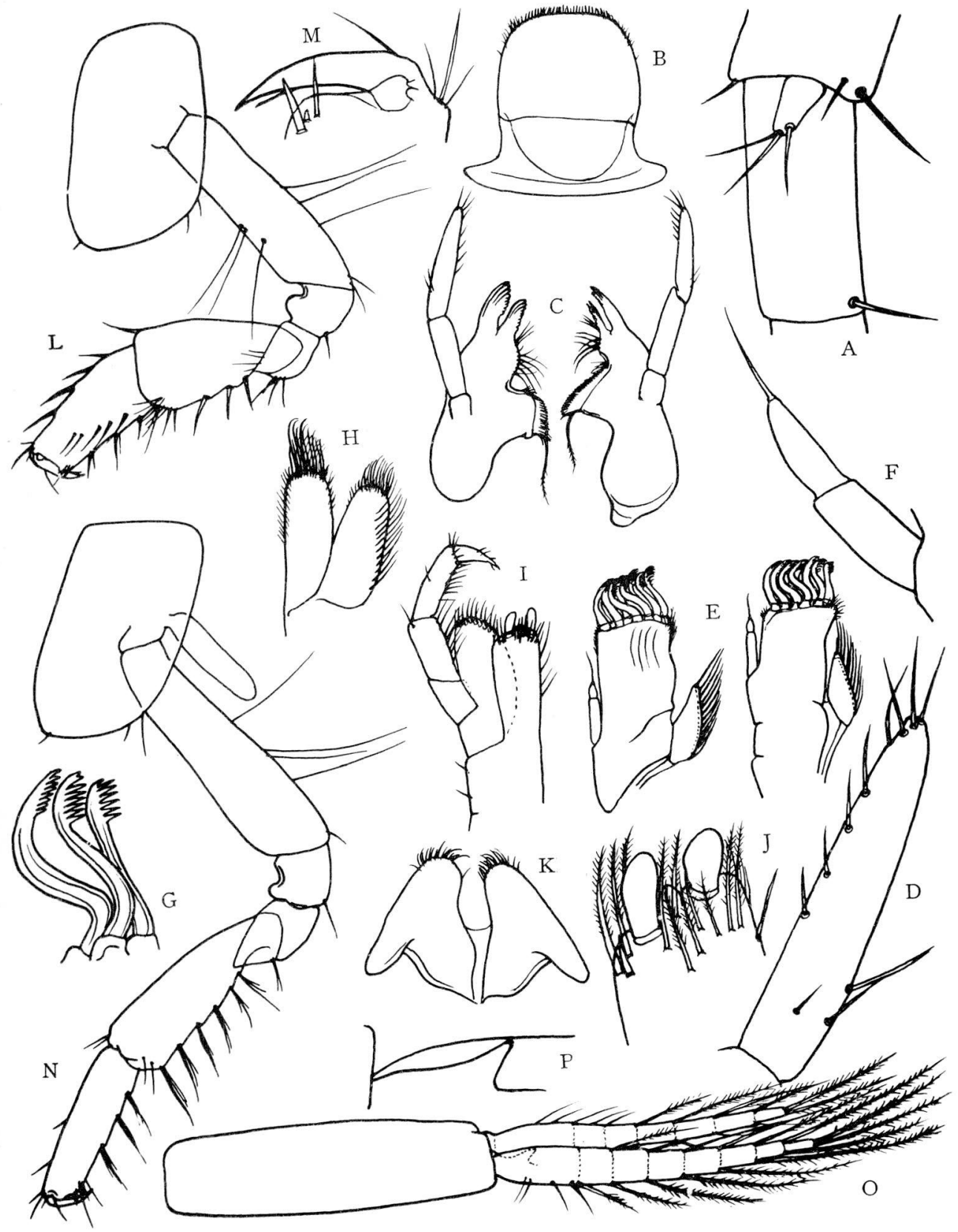




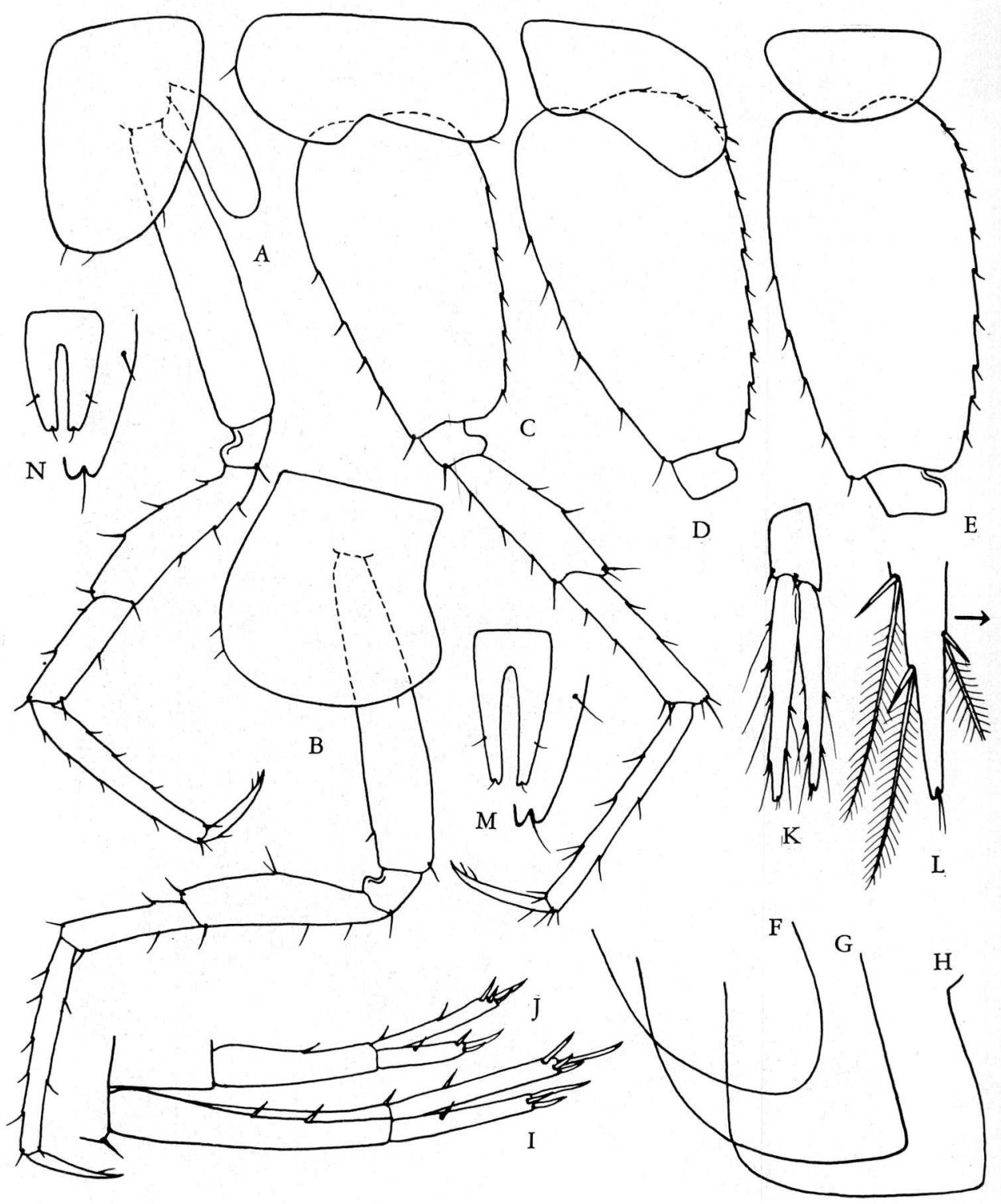

